\title{
Epidemiology of an Outbreak of Tuberculosis Among School Children
}

EVELYN F. H. ROGERS, M.D., M.P.H.

T JUNE 1958, the driver of bus 11 in the 1 Whitesboro School District, Oneida County, N.Y., was discovered to have active tuberculosis. A study of the school population indicated that 32 percent of the 266 children who rode with this driver reacted to the tuberculin test and that 19.5 percent of the group had active primary tuberculosis. The children who rode bus 11 attended five of the seven schools in the district. For all children in the seven schools who did not ride bus 11 , the tuberculin rate was 1.8 percent, and the rate for active primary tuberculosis was 0.1 percent. Among children who did not ride bus 11 but attended classes in the five schools with riders of bus 11 , the tuberculin reactor rate was 2.2 percent. This contrasted with a rate of 0.8 percent for children in the two remaining schools in the district which were not served by bus 11 . The rate for active primary tuberculosis, 0.1 percent, was the same in both groups of nonriders. Familial contacts of the reactors showed no unusual incidence of tuberculosis. No source other than the bus driver was found to be responsible for the spread of tubercle bacilli among children riding the bus.

Since tuberculosis mortality rates are low in this county, no unusual sequel was anticipated when the riders of bus 11 were routinely examined as contacts of the bus driver. However, this initial screening in June and July 1958 revealed a high tuberculin reactor rate and an unusual incidence of tuberculosis. Since the riders of bus 11 were scattered in five of the

Dr. Rogers is the health officer of the Utica District, New York State Department of Health. seven schools in the district, it seemed pertinent to search for contributing factors other than exposure to the bus driver which might have affected the children in these five schools. The remaining two schools which were not served by the bus driver with tuberculosis provided a suitable group for comparisons. These considerations led to an epidemiologic study of the whole school district during the next school year, 1958-59.

\section{Scope and Methods}

Participating in the project were the New York State Department of Health, through its Utica District office and the local State chest clinic, and the school officials, including a fulltime physician. County public health nurses were available for fieldwork.

The study was limited to students attending the district's schools in 1958-59 who had been present the preceding year, although all children in the schools in 1958-59 were offered the tuberculin test. The tuberculin survey was made approximately 3 months after tuberculosis was diagnosed in the bus driver. At the same time the test was repeated on the originally negative riders of bus 11 . The study period extended to July 1959 , one year after the original sceening of contacts.

The Mantoux test with purified protein derivative in a dosage of $0.00025 \mathrm{mg}$. was used. Reactions with induration of more than $5 \mathrm{~mm}$. were considered positive. No record was made of the size of the reactions in the early screening, but the measurement was recorded during the school survey and for any interim or repeated tests. 
Chest roentgenograms were made on all tuberculin reactors. Virtually all films were taken at the State chest clinic. Groups of children were transported by the school to the clinic and others were brought by parents. The private practitioners who cared for a few of the patients graciously lent their films for inclusion in the series.

Subsequent to the early screening of the bus riders and the school tuberculin survey, all examinations included a history and physical examination. The X-ray films were routinely read by the director of the State chest clinic, and those on all diagnosed or suspicious cases were reviewed by the radiologist of one of the State tuberculosis hospitals. When it was considered pertinent, lateral projections were made in addition to posteroanterior views. Fluoroscopy was used in many instances also, particularly to identify those lesions classed as healed primary lesions. The children treated at the State chest clinic were asked to return as often as was indicated in the judgment of the clinician, and the diagnoses were established through study of serial X-rays. By the end of October 1958, 80 percent of those considered to have active tuberculosis and 40 percent of those classed as having inactive disease had been so classified.

Riders of bus 11 with tuberculin reactions but negative roentgenograms were $\mathrm{X}$-rayed every 2 months during the year. Both posteroanterior and lateral projections were taken on all these children.

A biannual chest roentgenogram of all school personnel was made mandatory by the school board during the year 1958-59. Since 1952 such an examination had been required for bus drivers before employment and annually thereafter.

Familial contacts of all tuberculin reactors were studied in an attempt to uncover sources of infection in this group. History of known tuberculosis in the families was obtained, and efforts were made to tuberculin test or X-ray all household contacts. Any history of tuberculosis in family members was accepted as factual. If an individual with such a history had current or past contact with the child, he was included with family members found to have tuberculosis in the survey. The sum of these contacts was used to measure the school child's exposure to the disease during his lifetime. These data were analyzed to determine whether the reactors riding bus 11 differed from other children reacting positively with respect to familial exposure to tuberculosis.

During the tuberculin survey, the school teachers collected data on the school and class attended and the bus ridden by their students. The school transportation office provided lists of children assigned to ride bus 11 . When the data from these two sources differed, they were checked with the family and the child. This information was studied to see whether there was any association between cases or reactors and bus, classroom, or teacher.

The possibility of a relation between attack rates and seating arrangements or riding time on bus 11 was also considered. Previous experience with outbreaks in centralized schools has revealed the difficulty of obtaining accurate information on these items, but in this situation, with regulated bus runs, it appeared that such difficulties might be minimized. Seating arrangements were left to chance, but since bus stops were scheduled, time spent on bus 11 per day could be estimated fairly accurately. Information on riding time per day for each child, considered accurate to within 10 minutes, was obtained from the school transportation office for the regular daily trips. The bus was also operated for special events, driven sometimes by the regular driver and sometimes by other drivers. It was impossible to gather any reliable information on this irregular usage of the bus, but it seemed fair to assume that little importance need be attributed to this usage.

Special records were designed to supplement those used routinely in the tuberculosis control program. A final summary card for every student became the basis for tabulation.

\section{Epidemiologic Data}

School district. The Whitesboro School District in Oneida County serves an estimated population of 18,000 in an area of 55.5 square miles, most of which is suburban to the city of Utica, which has a population of 101,000. The district includes two incorporated villages with populations of 4,231 and 3,678 respectively. 
Table 1. Schools, grades, enrollment, and number of teachers in the Whitesboro School District, Oneida County, N.Y., 1957-58

\begin{tabular}{|c|c|c|c|c|}
\hline \multirow{2}{*}{ School } & \multirow{2}{*}{ Grades } & \multirow{2}{*}{$\begin{array}{l}\text { En- } \\
\text { roll- } \\
\text { ment }\end{array}$} & \multicolumn{2}{|c|}{$\begin{array}{l}\text { Number of } \\
\text { teachers }\end{array}$} \\
\hline & & & $\begin{array}{l}\text { Class- } \\
\text { room }\end{array}$ & $\begin{array}{l}\text { Spe- } \\
\text { cial }\end{array}$ \\
\hline All schools _ & $\mathrm{K}-12$ & 3,873 & 138 & 24 \\
\hline $\begin{array}{l}\text { Parkway }{ }^{1} \\
\text { Main Street } \\
\text { Harts Hill }{ }^{1} \\
\text { High School } 1 \\
\text { St. Paul's Parochial }{ }^{2} \\
\text { Marcy } \\
\text { Yorkville }\end{array}$ & $\begin{array}{l}7-8 \\
\mathrm{~K}-6 \\
\mathrm{~K}-6 \\
8-12 \\
\mathrm{~K}-4 \\
\mathrm{~K}-6 \\
\mathrm{~K}-4\end{array}$ & $\begin{array}{l}460 \\
605 \\
500 \\
810 \\
332 \\
803 \\
373\end{array}$ & $\begin{array}{r}19 \\
21 \\
16 \\
42 \\
9 \\
23 \\
8\end{array}$ & $\begin{array}{r}4 \\
5 \\
0 \\
11 \\
0 \\
2 \\
2\end{array}$ \\
\hline
\end{tabular}

1 Served by bus 11 .

${ }^{2}$ Includes public kindergarten of 112 students and 4 teachers, which was served by bus 11 .

Historically, the villages are mill towns and rural areas still exist, but the overall picture presents a rapidly growing suburban area with many new realty developments.

One high school serves the whole area. The five elementary schools serve sections of the district. One parochial school receives certain services from this school district and houses a public kindergarten; it is, therefore, included in the study.

All students were white.

The total district enrollment in 1957-58 averaged 3,873 , the number in each school varying from 322 to 810 (table 1). Classrooms numbered 107, and teachers, 162 . There were 38 school buses driven by 50 bus drivers over 156 routes. The school bus system served all public schools including the public kindergarten classes at St. Paul's, but service to the parochial division of St. Paul's was provided by a commercial bus company.

Tuberculosis mortality and morbidity. The tuberculosis death rate in Oneida County in 1958 was 6.3 per 100,000 , and the 3-year annual average for $1956-58$ was 4.8 per 100,000 .

The rate for new cases of tuberculosis in Oneida County in 1958 was 49.7 per 100,000, which was higher than the annual average of 33.5 per 100,000 for the previous 3 years (table 2). In the Whitesboro School District, the number of cases rose sharply in 1958. The case rate was 184.4 per 100,000 compared with an annual average for $1955-57$ of 19.7 per 100,000 . The increased rate in 1958, both in the county and the school area, reflects the cases reported in this outbreak.

Clinical history of bus driver. Some 8 months before he was employed, the driver of bus 11 was referred to the State chest clinic because of a cold with cough and scanty expectoration. On X-ray a soft mottled type of infiltration was noted in the left lung field. A diagnosis of an acute nonspecific pneumonitis was made, and although sputum examinations were recommended, the patient did not submit specimens. On February 2, 1957, another Xray showed incomplete resolution of the process; on March 16, 1957, definite clearing was noted. His next X-ray, on August 22, 1957, was required by the school when he sought employment as a bus driver. This film showed "complete clearing of the scattered bronchopneumonic type of infiltration, originally present on January 22, 1957." The man was hired as a bus driver for the school year 1957-58.

On June 9, 1958, the driver consulted a local physician. He gave a history of frequent and persistent "colds" beginning in January 1958, with a loss in weight of 30 pounds. By May 1958, he had developed night sweats, marked fatigue, and a more pronounced cough with expectoration. A clinical examination revealed abnormal chest signs; his physician referred him to the State chest clinic and subsequently to a chest specialist. A chest X-ray on June 10,

Table 2. Reported cases of tuberculosis in Oneida County and the Whitesboro School District, N.Y., 1955-58

\begin{tabular}{|c|c|c|c|c|}
\hline \multirow[b]{2}{*}{ Year } & \multicolumn{2}{|c|}{ Oneida County } & \multicolumn{2}{|c|}{$\begin{array}{c}\text { Whitesboro } \\
\text { School District }\end{array}$} \\
\hline & Cases & $\begin{array}{c}\text { Rate } \\
\text { per } \\
100,000 \\
\text { popula- } \\
\text { tion }\end{array}$ & Cases & $\begin{array}{c}\text { Rate } \\
\text { per } \\
100,000 \\
\text { popula- } \\
\text { tion }\end{array}$ \\
\hline $\begin{array}{l}1955 \\
1956 \\
1955-57, \text { annual } \\
\text { average } \\
1958\end{array}$ & $\begin{array}{r}104 \\
66 \\
64 \\
78 \\
719\end{array}$ & $\begin{array}{l}45.2 \\
28.3 \\
27.1 \\
33.5 \\
49.7\end{array}$ & $\begin{array}{r}4 \\
6 \\
7 \\
\\
56\end{array}$ & $\begin{array}{r}14.7 \\
20.9 \\
23.0 \\
19.7 \\
184.4\end{array}$ \\
\hline
\end{tabular}


1958, suggested a secondary lung abscess or neoplasm. The identification of tubercle bacilli in his sputum on June 20, 1958, established the diagnosis of tuberculosis, and he entered the sanatorium on June 2ో, 1958.

His symptoms in this last episode date back, therefore, to January 1958. He served as a bus driver for practically the whole school year, from September 2, 1957, when school opened, to June 20,1958 , his last day of work.

Description of bus 11. School bus 11 was a 1949 G.M.C. model, 37 feet by 8 feet by 10 feet, with a capacity to seat 55 and stand 11 . Five groups of children were transported daily on this bus in three morning and three afternoon runs. Only one group made a round trip. From 26 to 61 children were assigned to each load; the average was about 40 . In addition to this year-long schedule a sixth group of 25 children were driven one way to school for 30 days only.

The bus was equipped with two fan-type heaters, one situated to the left of the bus driver and the other midway in the bus. In addition to a defroster at the base of the windshield, two 6 -inch fans were installed, one on either side of and directed at the windshield. These devices when in use, plus frequent openings of the door, would undoubtedly deflect air from the front to the rear of the bus.

Buses were swept out once a week and washed inside "at least twice a year" with a mild disinfectant solution.

School survey. A request for the tuberculin test was received from the parents of 98 percent of the 4,200 students enrolled in the fall of 1958. Fewer children had attended the previ- ous year, and considerable turnover had occurred. Of the children surveyed, those who might correctly be included in this study numbered 3,667 , which was 94.5 percent of the average enrollment in 1957-58. Efforts to locate all students said to have ridden bus 11 produced all except three, whose status is unknown.

Of 266 students who rode bus 11 during 1957 58,85 , or 32.0 percent, had positive tuberculin tests (table 3). Active childhood type tuberculosis was diagnosed in 52 of these, or 19.5 percent, and inactive tuberculosis, in 6 , or 2.3 percent. The tuberculin positive bus riders included one child who had had BCG; he did not contract tuberculous disease. This group also includes seven late reactors found in the school survey on retesting the original negative bus riders. Of these, six were finally classified as active primary tuberculosis. Two of these showed parenchymal lesions, and one also had a pleural effusion. Among the 3,401 students who did not ride bus 11 , only 60 , or 1.8 percent, had a positive tuberculin test. In this group, 4 , or 0.1 percent, were considered to have active tuberculosis, and 24, or 0.7 percent, inactive disease. The difference in the proportion of tuberculin reactors and the difference in active tuberculosis rates between riders and nonriders are both highly significant statistically.

The tuberculin reactor rate was higher for children who did not ride bus 11 but attended school with those who rode than for children from other schools. For the former, the rate was 2.2 percent, and for the latter, 0.8 percent. The difference in the rates for reactors in these two groups is statistically significant, but the significance value is not of the magnitude

Table 3. Tuberculin reactors and fuberculosis cases according to association with bus 11 , Whitesboro School District survey, 1958-59

\begin{tabular}{|c|c|c|c|c|c|c|c|}
\hline \multirow{2}{*}{ Student group } & \multirow{2}{*}{$\begin{array}{c}\text { Number of } \\
\text { students } \\
\text { tested }\end{array}$} & \multicolumn{2}{|c|}{$\begin{array}{l}\text { Tuberculin } \\
\text { reactors }\end{array}$} & \multicolumn{2}{|c|}{$\begin{array}{l}\text { Active primary } \\
\text { tuberculosis }\end{array}$} & \multicolumn{2}{|c|}{$\begin{array}{l}\text { Healed primary } \\
\text { tuberculosis }\end{array}$} \\
\hline & & Number & Percent & Number & Percent & Number & Percent \\
\hline $\begin{array}{l}\text { Schools served by bus } 11 \text { : } \\
\text { Riders. } \\
\text { Nonriders } \\
\text { Other schools (nonriders) } \\
\text { All nonriders } \\
\text { All students }\end{array}$ & $\begin{array}{r}266 \\
2,296 \\
1,105 \\
3,401 \\
3,667\end{array}$ & $\begin{array}{r}85 \\
51 \\
9 \\
60 \\
145\end{array}$ & $\begin{array}{r}\text { 32. } 0 \\
\text { 2. } 2 \\
.8 \\
\text { 1. } 8 \\
\text { 4. } 0\end{array}$ & $\begin{array}{r}52 \\
3 \\
1 \\
4 \\
56\end{array}$ & $\begin{array}{r}\text { 19. } 5 \\
.1 \\
.1 \\
.1 \\
1.5\end{array}$ & $\begin{array}{r}6 \\
19 \\
5 \\
24 \\
30\end{array}$ & $\begin{array}{r}2.3 \\
.8 \\
.5 \\
.7 \\
.8\end{array}$ \\
\hline
\end{tabular}


found between rates for riders and all nonriders. A greater exposure to infection is suggested in these children associated with riders of bus 11 than in nonriders from other schools.

Of the 85 reactors who rode bus 11 the size of induration was recorded for only 17 . Of these, $3 \mathrm{had}$ an induration of 5-9 mm. in diameter; 10, an induration of 10-19 mm., and 4, an induration of more than $20 \mathrm{~mm}$. Of the 60 reactors not riding bus 11 , measurements were made for 42 . In this group, 21 showed an induration of 5-9 mm.; 17, 10-19 mm., and 4, more than $20 \mathrm{~mm}$.

Clinical status and treatment. All of the diagnosed cases in these children were classified as primary type. Details concerning their progress and clinical management have been reported elsewhere (1).

Briefly, all of the 52 children with active tuberculosis who rode the bus showed mediastinal adenopathy, and 15 were found to have a parenchymal lesion during the course of their disease. Two of the latter also had a pleural effusion. The culture from one gastric washing showed three types of acid-fast bacilli, Mycobacterium tuberculosis and anonymous mycobacteria types 2 and 3. Sputum from another patient was reported positive on concentration for Mycobacterium tuberculosis. In the other 50 active cases, the diagnosis could not be confirmed by laboratory examinations.

Fourteen of these 52 children were hospitalized, 11 others were treated at home by private physicians, and the remainder were treated by the director of the State chest clinic on an ambulant basis. Antimicrobial therapy was recommended for 69 of the 85 reactors who rode bus 11 , including all with active disease; it was accepted for 65 of these children, including all but 1 of those with active disease. Drug therapy was not recommended if the child was either a previously known reactor, had a healed lesion, or had a severe allergy.

Of the four active cases reported in those who did not ride bus 11, all were given antimicrobial therapy and one was hospitalized. Drug therapy was not prescribed for other tuberculin reactors among the nonriders, with the excep-

Table 4. Age distribution of tuberculin reactors and tuberculosis cases among riders and nonriders of bus 11, Whitesboro School District survey, 1958-59

\begin{tabular}{|c|c|c|c|c|c|c|c|}
\hline \multirow{2}{*}{ Age group (years) } & \multirow{2}{*}{$\begin{array}{l}\text { Number } \\
\text { of } \\
\text { students } \\
\text { tested }\end{array}$} & \multicolumn{2}{|c|}{$\begin{array}{l}\text { Tuberculin } \\
\text { reactors }\end{array}$} & \multicolumn{2}{|c|}{$\begin{array}{l}\text { Active primary } \\
\text { tuberculosis }\end{array}$} & \multicolumn{2}{|c|}{$\begin{array}{l}\text { Healed primary } \\
\text { tuberculosis }\end{array}$} \\
\hline & & Number & Percent & Number & Percent & Number & Percent \\
\hline \multicolumn{8}{|l|}{ Riders } \\
\hline All ages_- & 266 & 85 & 32.0 & 52 & 19. 5 & 6 & 2. 3 \\
\hline $10-149$ & $\begin{array}{r}12 \\
131 \\
92 \\
31\end{array}$ & $\begin{array}{r}5 \\
36 \\
31 \\
13\end{array}$ & $\begin{array}{l}41.7 \\
27.5 \\
33.7 \\
41.9\end{array}$ & $\begin{array}{r}5 \\
24 \\
17 \\
6\end{array}$ & $\begin{array}{l}41.7 \\
18.3 \\
18.5 \\
19.4\end{array}$ & $\begin{array}{l}0 \\
1 \\
5 \\
0\end{array}$ & $\begin{array}{l}0 \\
.8 \\
5.4 \\
0\end{array}$ \\
\hline \multicolumn{8}{|l|}{ Nonriders } \\
\hline All ages_. & 3,401 & 60 & 1. 8 & 4 & .1 & 24 & .7 \\
\hline $10-14$ & $\begin{array}{r}220 \\
1,302 \\
1,292 \\
587\end{array}$ & $\begin{array}{r}0 \\
7 \\
26 \\
27\end{array}$ & $\begin{array}{l}0 \\
2.5 \\
4.6\end{array}$ & $\begin{array}{l}0 \\
0 \\
4 \\
0\end{array}$ & $\begin{array}{l}0 \\
0 \\
0\end{array}$ & $\begin{array}{r}0 \\
4 \\
11 \\
9\end{array}$ & $\begin{array}{r}0 \\
.3 \\
.9 \\
1.5\end{array}$ \\
\hline \multicolumn{8}{|l|}{ All students } \\
\hline All ages & 3,667 & 145 & 4.0 & 56 & 1.5 & 30 & .8 \\
\hline $\begin{array}{l}50-14 \\
15 \\
15\end{array}$ & $\begin{array}{r}232 \\
1,433 \\
1,384 \\
618\end{array}$ & $\begin{array}{r}5 \\
43 \\
57 \\
40\end{array}$ & $\begin{array}{l}\text { 2. } 2 \\
\text { 3. } 0 \\
\text { 4. } 1 \\
\text { 6. } 5\end{array}$ & $\begin{array}{r}5 \\
24 \\
21 \\
6\end{array}$ & $\begin{array}{l}\text { 2. } 2 \\
\text { 1. } 7 \\
\text { 1. } 5 \\
\text { 1. } 0\end{array}$ & $\begin{array}{r}0 \\
5 \\
16 \\
9\end{array}$ & $\begin{array}{l}0 \\
.3 \\
1.2 \\
1.5\end{array}$ \\
\hline
\end{tabular}


tion of one child who was first thought to have ridden the bus.

Age and sex distribution. Distribution by sex was not remarkable for either reactors or cases.

The age distribution of reactors and tuberculosis patients among riders and nonriders of bus 11 was, however, of interest, even though definite conclusions cannot be drawn because of the small number in the rider group (table 4). For riders, the tuberculin reactor rate was highest in the 5-year age group (41.7 percent) ; there were no reactors of this age among nonriders. Six-year-old riders had the lowest rate (18.4 percent, or 7 of 38 ) ; thereafter the rates tended to increase with age. For nonriders the rates increased significantly and progressively by age, reaching 4.6 percent in those 15 years and over.

Among riders the relationship of active disease to tuberculin reaction by age is also noteworthy. In the 5-year group all five reactors were considered to have active tuberculosis; in the age group 6-9 years 24 of 36 , or 67 percent, were considered to have active disease; in the group 10-14 years, 17 of 31 , or 55 percent, and in the group 15 years and over, only 6 of 13 , or 46 percent, were so classified. The probability of obtaining such a trend by chance would be expected only 4 times in 100 .
This trend illustrates that except perhaps for the 5-year-olds, the younger children appeared less likely to become tuberculin positive, but they were more likely to develop active disease after conversion of the tuberculin test than the older group.

Contact study. The contact study included all families of the 145 positive reactors. There were 75 families of the 85 positive reactors who rode bus 11 and 49 families of the 60 reactors who did not ride this bus, 114 families in all. Nearly 85 percent of all contacts in these families were examined. In 18 , or 24 percent, of the families of reactors who rode bus 11 and in 19 , or 38 percent, of families of reactors who did not ride this bus, not all members were examined.

Considering only familial contacts who did not attend school, the amount of tuberculosis among the contacts of riders of bus 11 did not differ significantly from that among contacts of nonriders (table 5). For contacts of riders, 6.8 percent were found to have tuberculosis or a history of tuberculosis; for contacts of nonriders, 5.6 percent fell in this category. No tuberculosis was found among preschool children in either group. Rates for adult household contacts were 5 percent and 3.3 percent respectively. Rates for the two groups of extrahousehold contacts were 17.8 percent and 25

Table 5. Tuberculosis among familial contacts of tuberculin reactors, Whitesboro School District survey, 1958-59

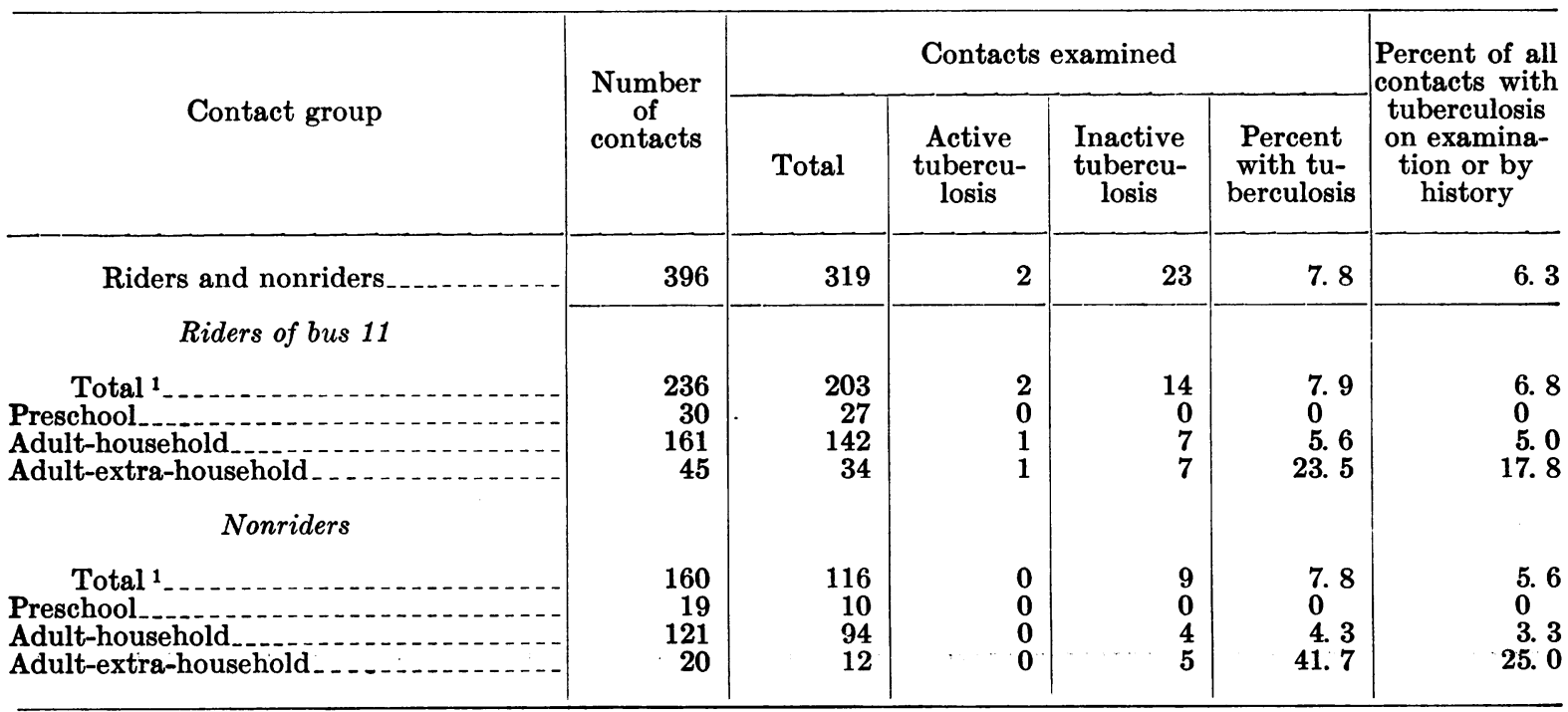

1 Exclusive of students. 
percent. The latter probably are not valid, however, since information concerning other than immediate family members tends to be inaccurate.

Some contact with an individual giving a history of tuberculosis other than the driver of bus 11 was revealed for about one-sixth of all tuberculin reactors, whether they were $(a)$ riders of bus 11, (b) nonriders, $(c)$ those with a positive skin test only, or $(d)$ those with active or inactive disease.

Examination of school personnel. Chest roentgenograms were taken of all school personnel employed in any capacity in 1958-59, and all were found negative. Of the 37 school teachers or bus drivers who left the district at the end of the 1957-58 school year, all except 2 were located. A negative chest $\mathrm{X}$-ray report was received on these 35 . The children who rode bus 11 were scattered throughout 13 grades and 107 classrooms in 5 schools. The association of positive reactors with school teachers or buses was analyzed, but no significant correlation was found except for bus 11 .

Length of exposure. The study of attack rates by riding time on bus 11 on its regular daily trips revealed a trend toward an increase in the rate for tuberculin reactors with increased riding time, although the tuberculosis case rate showed no consistent trend (table 7). For children riding less than 10 minutes per day the tuberculin reaction rate was 21.6 percent. With increased riding time, by 10-minute intervals, the rate rose irregularly to 50 percent for those riding 40 to 49 minutes per day. Those who rode 50 minutes or more had a reaction rate of 62.5 percent. The probability of this distribution occurring by chance is 5 times in 100 . In another grouping, a reactor rate of 28.9 percent for all riding less than 40 minutes, contrasts with a rate of 56.7 percent for those who rode longer. The probability of this difference occurring by chance is 1 in 100. ' Other distributions do not give significant results, nor do the four riding-time groups under 40 minutes show any consistent trend.

The relation of tuberculin sensitivity to riding time according to age and sex was also analyzed. No child under 10 years rode as long as 40 minutes per day. For the age group 10 years and over, a significant difference occurs between those riding less than 40 minutes and those riding 40 minutes or more. This suggests that the significance is not due to age distribution.

The experience of one kindergarten class tends to uphold the expected effect of increased exposure on the attack rate. In this class of 30 children, aged 5 and 6 years, 25 rode bus 11 to school in the morning for 30 days only, between January 27 and March 10, 1958. The other five were transported for the same daily trip for the whole school year. In the first group of 25 , 4 had a positive tuberculin test. One of these

\section{Table 6. Number and proportion of tuberculin reactors and active primary tuberculosis patients}

among riders on bus 11 , Whitesboro School District survey, by riding time per day

\begin{tabular}{|c|c|c|c|c|c|}
\hline \multirow{2}{*}{ Riding time per day (minutes) } & \multirow{2}{*}{$\begin{array}{l}\text { Number of } \\
\text { students }\end{array}$} & \multicolumn{2}{|c|}{ Tuberculin reactors } & \multicolumn{2}{|c|}{ Active primary tuberculosis } \\
\hline & & Number & Percent & Number & Percent \\
\hline Total & 266 & 85 & 32.0 & 51 & 19. 2 \\
\hline $\begin{array}{l}\text { Less than } 101 \\
10-19 \\
20-29 \\
30-39 \\
40-49 \\
50 \text { or more } \\
\text { Not stated }\end{array}$ & $\begin{array}{r}37 \\
95 \\
74 \\
22 \\
14 \\
16 \\
8\end{array}$ & $\begin{array}{r}8 \\
32 \\
20 \\
6 \\
7 \\
10 \\
2\end{array}$ & $\begin{array}{l}\text { 21. } 6 \\
\text { 33. } 7 \\
27.0 \\
27.3 \\
50.0 \\
62.5 \\
25.0\end{array}$ & $\begin{array}{r}7 \\
20 \\
13 \\
2 \\
4 \\
5 \\
0\end{array}$ & $\begin{array}{r}\text { 18. } 9 \\
21.1 \\
17.6 \\
9.1 \\
28.6 \\
31.3 \\
0\end{array}$ \\
\hline $\begin{array}{l}\text { Less than } 40 \\
40 \text { or more }\end{array}$ & $\begin{array}{r}228 \\
30\end{array}$ & $\begin{array}{l}66 \\
17\end{array}$ & $\begin{array}{l}28.9 \\
56.7\end{array}$ & $\begin{array}{r}42 \\
9\end{array}$ & $\begin{array}{l}\text { 18. } 4 \\
\text { 30. } 0\end{array}$ \\
\hline
\end{tabular}

1 Includes those who rode the bus occasionally or only 30 days. On a school-year basis, their average riding time per day would be less than 10 minutes. 
was a known reactor following $B C G$ raccination. Excluding him, this is a rate of 12 percent. In the other group of five, four had a positive tuberculin test, a rate of 80 percent. In this small group, therefore, the reactor rate for children riding the bus all year was 80 percent as compared with 12 percent for those who rode only 30 days.

However, another interesting observation concerns a girl who rode bus 11 in her wheelchair. The driver lifted her on and off during the whole year and she sat in her chair beside him. Her tuberculin test remained negative.

Community $X$-ray survey. About 3,000 persons, or 21 percent of the residents over 15 years of age in the school district, received a photoroentgenogram in a community survey. Seven inactive cases, previously unknown, were diagnosed, but no new active cases were discovered.

\section{Discussion}

In the 114 families of the positive reactors, no unusual incidence of tuberculosis was observed. Families of children riding bus 11 did not appear to differ from families of nonriders with respect to exposure to tuberculosis. If the reactor rate of 1.8 percent found for all nonriders is applied to the group of 266 who rode bus 11, the expected number of reactors is 5 . The 85 reactors observed was 17 times this expected number. Exposure to the bus driver, the only common source found, appeared to be responsible for this excess.

Only two active cases of tuberculosis were found in the families of nonriders among contacts not attending school. This finding also suggests that the majority of the group were infected through exposure to the bus driver.

The less striking but true higher reactor rate for nonriders associated in school with riders of bus 11 again implicates the bus driver as a causative factor. These children might have had casual or occasional contact with the driver on his regular runs or to special events. Or the infection might have been transmitted from infected classmates.

The two schools in the district, Marcy and Yorkville, which had no contact with bus 11 or the infected bus driver, enrolled children from kindergarten through the sixth grade only.
The combined reactor rate of 0.8 percent for children in these schools perhaps reflects more accurately what may be expected in a community with low tuberculosis rates.

Negative findings in essentially all school personnel except the driver of bus 11 lends further support to the presumption that this man played the major role in the dissemination of the tubercle bacillus among the children known to have been in contact with him and possibly to their associates as well.

Had any exceptional number of unknown active cases of tuberculosis existed in the adult population, it seems reasonable to assume that these would have been discovered during the year either in the survey or through the regular tuberculosis control program.

\section{Summary and Conclusion}

Nearly 4,000 children in the Whitesboro School District, Oneida County, N.Y., were given tuberculin tests, and all positive reactors were $\mathrm{X}$-rayed as a sequel to the diagnosis of tuberculosis in the driver of school bus 11 .

In the whole district, 145 , or 4 percent, of the children reacted to tuberculin, and 56, or 1.5 percent, were considered to have active childhood tuberculosis.

Significantly higher rates occurred in children who either rode with the bus driver or attended schools served by bus 11 than in children from other schools in the district. The tuberculin reaction rates were 32 percent for children riding this bus, 2.2 percent for children attending the same schools, and 0.8 percent for children from other schools. The rates for active tuberculosis were 19.5 percent for children riding the bus and 0.1 percent for all other children.

The factors responsible for higher attack rates in children attending school with riders of bus 11 were not clearly determined.

With the exception of a small group of 5 year-old children, it appeared that although the younger age groups were less likely to show tuberculin sensitivity on exposure to tuberculosis, they were more likely to develop active disease after conversion of the tuberculin test than the older groups.

No unusual incidence of tuberculosis was dis- 
covered in the familial contacts of the tuberculin reactors or of the children with tuberculosis. No tuberculosis was found in the school persomnel other than in the one bus driver.

A trend was noted toward a rise in reactor rates with increasing riding time on bus 11 .

It seems reasonable to conclude that the bus driver was the source of infection for those children who constituted the excess of the observed over the expected number of reactors and cases among riders of bus 11 .

\section{REFERENCE}

(1) Mahady, S. C.: An outbreak of primary tuberculosis in school children. Am. Rev. Resp. Dis. 84 : 348-358, September 1961.

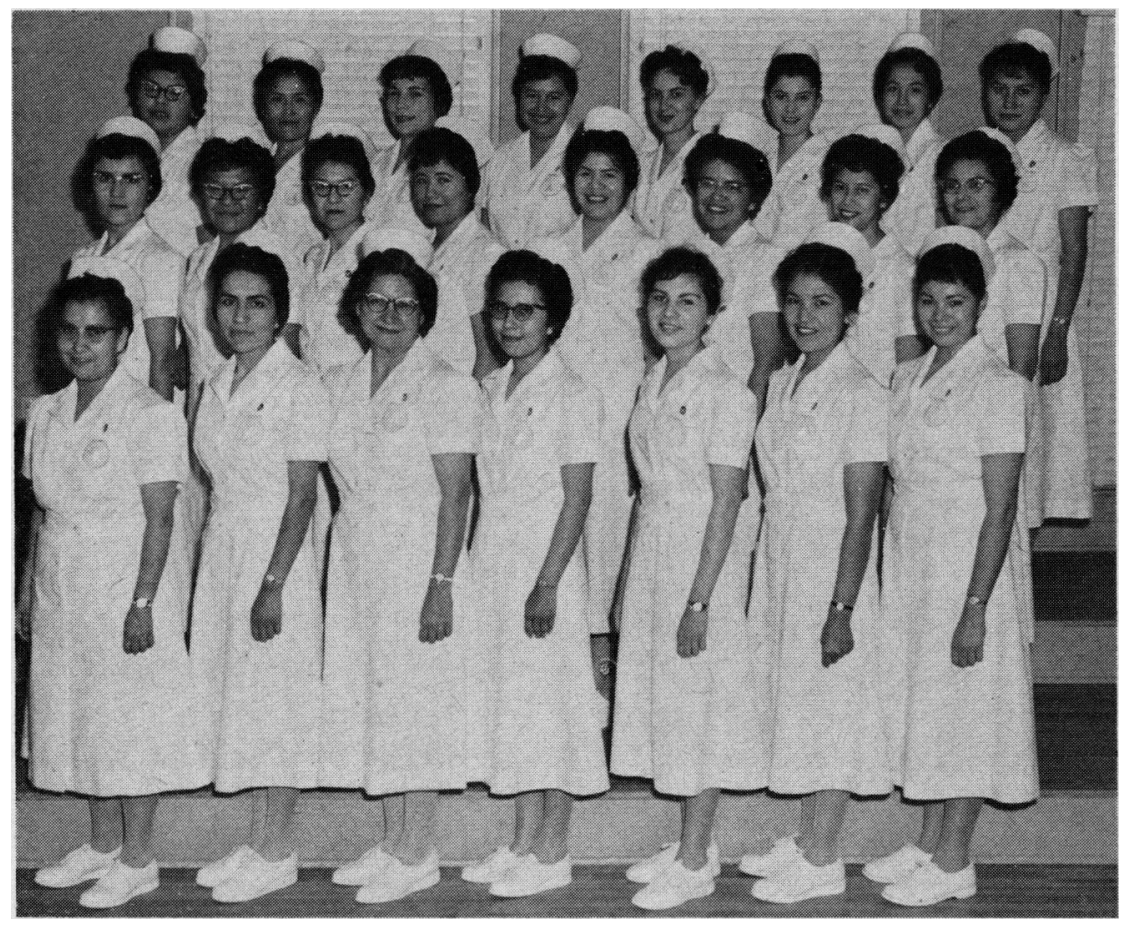

\section{Indian School of Practical Nursing}

The Public Health Service's Indian School of Practical Nursing in Albuquerque, N. Mex., graduated 23 students on February 28, 1962. The graduates will be placed throughout the country with facilities of the Division of Indian Health.

The school was first established in Lawton, Okla., in 1935 to provide an opportunity for young Indian girls to obtain training in a useful occupation and to supply hospitals with a group of workers with an understanding of the Indian.

Applicants for admission to the school must have one-fourth or more degree of Indian blood and must have completed high school. The 1-year course is accredited by the State of New Mexico and the National Association for Practical Nursing. 


\section{Student Companions for Mental Patients}

Since November 1958, selected chronic patients in a male psychiatric service of the Veterans Administration neuropsychiatric hospital in Topeka, Kans., have been receiving weekly "companionship" visits from students in nearby Washburn University. The project is the largest of three volunteer companionship projects being supervised by the hospital's social work service.

So far 55 men and women students have participated as companions to patients selected for the program by hospital psychiatrists. Matching of volunteers to patients is based chiefly on age, sex, the kind of relationship desired (such as fatherdaughter, brother-sister, or brother-brother relationships), mutual interests, and interviews of volunteers by psychiatrists.

The volunteers are allowed the run of the hospital's patient activity areas and, with medical approval, also accompany patients to activities off hospital grounds. Typical activities are reading together, playing games, taking walks, visiting the canteen, and pursuing hobbies.

The social worker in charge of the project or a substitute usually meets with each volunteer just prior to each weekly visit to give him supervision and to discuss problems. Each volunteer keeps a notebook in which he reports to the patient's psychiatrist and the social worker each visit, giving impressions and raising questions. The psychiatrists, social workers, psychologists, and Washburn University faculty members who have an interest in the project meet periodically to discuss its progress.

Surprising, sometimes even dramatic, responses to the student companions have been observed in the patients. Some who had been extremely withdrawn for years have entered readily and eagerly into conversation and activities with their student companions. At the other extreme, some patients who had shown a great deal of interest in having students visit them soon found the visits too threatening and quickly withdrew.

Sixteen psychiatrists evaluating the condition of patients who had received visits for most of a school year rated 17 patients as better or much better, 11 as undergoing little or no change, and 1 as worse. The therapeutic influence of the visits was rated slightly positive, moderately positive, or very positive in 26 out of 29 instances. The patients' response to volunteer companionship activities was rated as more favorable than to any other activity or more favorable than to most other activities in 22 out of 29 instances.

These ratings may only reflect the general acceptance by the professional staff of companionship activities as part of the hospital's treatment program. However, they also support the many specific instances that have been observed of favorable response by patients to this personal approach, in contrast to a few isolated instances of unfavorable response.

Recruitment of volunteer companions is undertaken at the beginning of each semester at Washburn. A description of the program is presented to two classes in general psychology by someone from the hospital who is closely connected with the program. The classes contain about 225 students who are at least of a sophomore level. Following the presentation, students who submit an application to become volunteer companions are invited to a meeting at which the project is discussed in greater detail and to two orientation sessions. These sessions are a national requirement of the Veterans Administration for certification of new volunteers. Students who complete the sessions are interviewed by psychiatrists from the hospital who request companions for certain patients.

The effect of the visits on the volunteers has been varied and unpredictable. Some students who at first seemed insecure about venturing into the experience turned out to be effective, conscientious, and durable. Others who made the initial impression of being mature, bright, and well-motivated screened themselves out for various reasons. The opportunity for university students to receive serious experience in mental health work has been one of the program's important added benefits.-HAROLD W. Feldman, M.A., A.C.S.W., assistant chief, social work service, Veterans Administration Hospital, Topeka, Kans. 